\title{
Above- and below-ground biomass and carbon stocks of different tree plantations in central Iran
}

\author{
Hormoz SOHRABI ${ }^{1 *}$, Siavash BAKHTIARVAND-BAKHTIARI ${ }^{2}$, Kourosh AHMADI ${ }^{1}$ \\ ${ }^{1}$ Faculty of Natural Resources and Marine Science, Tarbiat Modares University, Tehran 14115, Iran; \\ ${ }^{2}$ Faculty of Natural Resources and Earth Science, University of Shahrekord, Shahrekord 88186, Iran
}

\begin{abstract}
In arid and semi-arid lands using industrial wastewater for irrigating tree plantations offers a great opportunity to fulfill the purpose of Clean Development Mechanism by sequestering carbon in living tissues as well as in soil. Selection of tree for plantation has a great effect on the goal achievements, especially when the managers deal with afforestation projects rather than reforestation projects. The objective of this study was to quantify the above- and below-ground biomass accumulation and carbon storages of the 17-year-old monoculture plantations of mulberry (Morus alba L.), black locust (Robinia pseudoacacia L.), Eldar pine (Pinus eldarica Medw.) and Arizona cypress (Cupressus arizonica Greene) planted in central Iran. To assess the potential carbon storage, we destructively measured individual above- and below-ground tree biomass and developed and scaled models at stand level. Furthermore, carbon content at three soil depths $(0-15,15-30,30-45$ $\mathrm{cm}$ ), the litter and the understory were assessed in sample plots. The results showed that the total amount of carbon stored by Eldar pine $\left(36.8 \mathrm{Mg} / \mathrm{hm}^{2}\right)$ was higher than those stored by the trees in the other three plantations, which were $23.7,10.0$, and $9.6 \mathrm{Mg} / \mathrm{hm}^{2}$ for Arizona cypress, mulberry and black locust plantations, respectively. For all the species, the above-ground biomass accumulations were higher than those of the below-ground. The root mass fractions of the deciduous were larger than those of the coniferous. Accordingly, the results indicate that the potential carbon storages of the coniferous were higher than those of the deciduous in arid regions.
\end{abstract}

Keywords: carbon storage; biomass; coniferous; deciduous; central Iran

Citation: Hormoz SOHRABI, Siavash BAKHTIARVAND-BAKHTIARI, Kourosh AHMADI. 2016. Above and below-ground biomass and carbon stocks of different tree plantations in arid land. Journal of Arid Land, 8(1): 138-145. doi: 10.1007/s40333-015$0087-\mathrm{z}$

Carbon dioxide $\left(\mathrm{CO}_{2}\right)$ is the most important anthropogenic greenhouse gas that plays the greatest role in global warming ( $\mathrm{Li}$ et al., 2014). Human activities for reducing atmospheric $\mathrm{CO}_{2}$ were started when the effects of global warming were specified. After ratification of the Kyoto Protocol, two different actions have been taken for reducing $\mathrm{CO}_{2}$ emissions: reducing human activities related to greenhouse gas emission; creating and improving carbon sinks in the biosphere by tree plantation (Bipal and Mrinmo, 2010; Aguirre-Salado et al., 2014). Trees play an important role in reducing $\mathrm{CO}_{2}$ by absorbing and accumulating it in their leaves, branches, stems and roots as biomass (McPherson and Simpson, 1999). Biomass has been widely used for carbon cycle studies because it is an important indicator of vegetation growth and dynamic (Yan et al., 2013).

Establishing tree plantations in the vicinity of industrial areas is one of the mandatory Iranian environmental laws (Abdinezhad, 2012). Reforestation and afforestation projects have been in operation annually in Iran after the Clean Development Mechanism projects evolved since 1990. 
Many of these plantations are watered by industrial waste water due to the shortage of the clean water in the area.

Forest managers are interested in increasing the productivity of the planted forests and the timber production which accordingly can increase the carbon sequestration rates (Lemus and Lal, 2005; Woodbury et al., 2007). The simplest way to achieve this goal is to select proper species for plantation. To understand the effects of the different tree species on forest carbon storage and to determine the most appropriate reforestation species and forest management strategies (Zheng et al., 2008), it is necessary to examine the differences of carbon pools among the different plantations (Kaul et al., 2010).

During the last century, selected deciduous and coniferous species have been planted in different areas in Iran. However, no enough information is available for managers on how to select the proper species with high carbon storage capacities under certain climatic conditions. In this research, we aimed to compare the carbon storage potential in the above- and below-ground parts of the four 17year old monoculture plantations of the deciduous, mulberry (Morus alba L.) and black locust (Robinia pseudoacacia L.), and the coniferous, Eldar pine (Pinus eldarica Medw.) and Arizona cypress (Cupressus arizonica Greene). To our knowledge, the potential of carbon storage of coniferous and deciduous species has been examined in numerous studies, but not much on the amount of carbon stored in the above- and below-ground tree parts, particularly in arid areas.

\section{Study area}

The study was conducted at a manmade forest in Mobarakeh Steel Company, Isfahan province. The study site is located approximately $75 \mathrm{~km}$ southwest away from Isfahan city in central Iran $\left(32^{\circ} 13^{\prime}-\right.$ $32^{\circ} 17^{\prime} \mathrm{N}, 51^{\circ} 23^{\prime}-51^{\circ} 27^{\prime} \mathrm{E}$ ), with a mean annual precipitation of $160 \mathrm{~mm}$, a mean annual evaporation of $1,750 \mathrm{~mm}$ and a 30 -year annual mean temperature of $15^{\circ} \mathrm{C}$. The mean growth period was 155 days. The soil textures are dominated by clay, silt-clay, loam-silt and loam-silt-clay. Table 1 shows the soil properties of a control site at different soil depths $(0-15,15-30$ and $30-45 \mathrm{~cm})$.

About $1,500 \mathrm{hm}^{2}$ in this area has been planted with trees, including mulberry (M; Morus alba L.), black locust (BL; Robinia pseudoacacia L.), Eldar pine (EP; Pinus eldarica Medw.) and Arizona cypress (AC; Cupressus arizonica Greene). The areas of the plantations, with the same age and environmental conditions, were approximately 400, 200, 200 and $100 \mathrm{hm}^{2}$ for EP, AC, M and BL, respectively (Table 2). These forests have been irrigated by wastewater from Mobarakeh Steel Company through a drip irrigation system.

Table 1 Soil properties of the study area

\begin{tabular}{lccc}
\hline \multirow{2}{*}{ Soil properties } & \multicolumn{3}{c}{ Soil depth $(\mathrm{cm})$} \\
\cline { 2 - 4 } $\mathrm{pH}$ & $0-15$ & $15-30$ & $30-45$ \\
Electrical conductivity (dS/m) & 7.50 & 7.50 & 7.55 \\
Organic carbon (\%) & 1.60 & 4.40 & 2.30 \\
Total nitrogen (\%) & 0.14 & 0.12 & - \\
Potassium (mg/kg) & 0.01 & 0.01 & - \\
Gypsum (\%) & 170.00 & 146.00 & - \\
\hline
\end{tabular}

Note: -, not detected.

Table 2 Stand characteristics of the different tree plantations

\begin{tabular}{lcccc}
\hline Stand properties & Black locust & Mulberry & Arizona cypress & Eldar pine \\
\hline Diameter at breast height $(\mathrm{cm})$ & - & - & 10.5 & 17.8 \\
Total height $(\mathrm{m})$ & 4.7 & 4.6 & 6.4 & 10.9 \\
Crown width $(\mathrm{m})$ & 3.4 & 4.0 & 2.1 & 3.2 \\
Stand age (year) & 17 & 17 & 17 & 17 \\
Stand density (individual $\left./ \mathrm{hm}^{2}\right)$ & 2,833 & 3,000 & 3,048 & 3,071 \\
Plantation area $\left(\mathrm{hm}^{2}\right)$ & 100 & 200 & 200 & 400 \\
\hline
\end{tabular}

Note: -, non-measurable characteristics. 


\section{Methods}

\subsection{Tree biomass measurement}

In order to measure biomass of the four species, we randomly selected 12 plots in each stand (48 plots in total). The standing tree variables including diameter at breast height (DBH), crown width (CW) and total height $(\mathrm{TH})$ were measured for $\mathrm{EP}$ and $\mathrm{AC}$. But for $\mathrm{M}$ and $\mathrm{BL}, \mathrm{DBH}$ were not measured because the trees were multi-stemmed under breast height and DBH was not a representative variable for tree dimension. The trees were stratified into 5 strata based on the range of DBH and TH. In each stratum, 3 individuals were selected randomly and were cut down (15 individuals for each species). The entire size range of each species was represented accordingly.

After cutting down the trees, the above-ground parts of the trees were separated as stem, stem bark, branch, twig (diameter at the base $<1 \mathrm{~cm}$ ) and foliage to measure the above-ground biomass. The total fresh weight of each part was measured in situ. Then, 5 trees from each species were selected and their roots were completely dug out by a mechanical shovel to determine the below-ground biomass. The weight of roots with diameters $>2 \mathrm{~mm}$ was measured.

The entire tissue samples were collected from each part of the trees and representative subsamples were removed using chainsaw and branch clipper to determine water content. All tissues were dried to constant weight at $80^{\circ} \mathrm{C}$. The percentage of carbon in all samples was determined using combustion method.

\subsection{Forest floor and soil carbon pool}

In each plot, we established two $4.0 \mathrm{~m} \times 4.2 \mathrm{~m}\left(16.8 \mathrm{~m}^{2}\right)$ subplots and measured the forest floor litter and understory vegetation by collecting the litter and clipping the vegetation. The collected materials were combined and weighed in situ. Then a subsample was taken and transported to the laboratory and dried at $80^{\circ} \mathrm{C}$. Combustion method was used for determining carbon concentrations of different tissues (TSI Incorporated, 2004).

In each stand, three plots were selected randomly and a combined soil sample was selected in each plot (totally 12 soil samples). The soil samples were collected down to the depth of $45 \mathrm{~cm}(0-15,15-$ 30 and $30-45 \mathrm{~cm})$. Furthermore, in fallow fields adjacent to each stand, three soil samples were randomly collected as the control treatment. All soil samples were air-dried and sieved $(2 \mathrm{~mm})$ prior to determining the total organic carbon by using the Walkley-Black method (Schumacher, 2002). Bulk density was determined for each sample using clod method (Prihar and Hundal, 1971).

\subsection{Calculation of carbon storage and statistical analyses}

We used regression analysis based on power function to determine the allometric relationship of biomass for different tree components and standing tree variables (Verwijst and Telenius, 1999). The independent variable for $\mathrm{AC}$ and $\mathrm{EP}$ was diameter at breast height and the total height for M and BL. Then, we applied the derived allometric equations to estimate biomass of standing trees in the plots to upscale biomass and carbon at per stand level.

The normality of the data was explored by the Kolmogorov-Smironov test. One-way analysis of variances (ANOVA) was used to test the significant differences in carbon concentration, biomass and carbon pools among the four plantations. Once a significant difference was detected, Tukey's various range test was applied to examine the difference between the averages of the treatments at the significance level of $P<0.05$.

\section{Results and discussion}

\subsection{Tree biomass and carbon storage}

Table 3 shows the mean and standard error for biomass of each tree component in EP, AC, M and and BL plantations. The highest carbon storage in above-ground components was recorded for the EP plantation $\left(50.62 \mathrm{Mg} / \mathrm{hm}^{2}\right)$, followed by the $\mathrm{AC}\left(25.72 \mathrm{Mg} / \mathrm{hm}^{2}\right)$, while the lowest amount of 
stored carbon was found in the $\mathrm{M}\left(9.87 \mathrm{Mg} / \mathrm{hm}^{2}\right)$ and the $\mathrm{BL}\left(8.85 \mathrm{Mg} / \mathrm{hm}^{2}\right)$. The same comparable results were found for the below-ground biomass (Table 3 ).

Our finding is similar to the study by Coyle et al. (2008) which showed that the annual rate of carbon storage is higher in the coniferous than in the deciduous trees. Since climatic conditions and site properties of our studied plantations were the same, the reason for the differences in carbon storage level lies in the difference of the capability in the above-ground biomass production of the coniferous, which start to assimilate earlier in the growth season and continue to assimilate longer. Also, the coniferous grow faster than the deciduous in warmer climates (Schulze et al., 2005). Furthermore, coniferous have an important additional advantage on having only a fraction of their assimilating organs renewed every year, while the deciduous trees renew the complete leaf mass (Schulze et al., 2005) annually. Thus, coniferous are able to compensate their lower physiological activity per gram of leaves (Poorter et al., 2012).

The below-ground biomass varied among the plantations (Table 3) and the EP plantation had the highest biomass. The below-ground biomass proportion is affected by a combination of resource availability and stand age (Coyle et al., 2008). In this study, climate conditions, soil properties, irrigation intervals and tree ages for all the species were similar so the main reason for the variation in the below-ground carbon storage between the plantations was species-specific.

Table 3 Biomass of the tree components for the four tree species

\begin{tabular}{ccccc}
\hline \multirow{2}{*}{ Tree parts } & EP & AC & M & BL \\
\cline { 2 - 4 } & \multicolumn{4}{c}{ Biomass $\left(\mathrm{Mg} / \mathrm{hm}^{2}\right)$} \\
Stem wood & $23.92 \pm 0.37^{\mathrm{a}}$ & $10.52 \pm 0.90^{\mathrm{b}}$ & $3.43 \pm 0.14^{\mathrm{c}}$ & $2.73 \pm 0.17^{\mathrm{c}}$ \\
Stem bark & $3.85 \pm 0.11^{\mathrm{a}}$ & $1.59 \pm 0.12^{\mathrm{c}}$ & $1.16 \pm 0.04^{\mathrm{c}}$ & $2.34 \pm 0.15^{\mathrm{b}}$ \\
Branch & $13.73 \pm 0.26^{\mathrm{a}}$ & $4.28 \pm 0.39^{\mathrm{b}}$ & $3.98 \pm 0.08^{\mathrm{b}}$ & $2.45 \pm 0.15^{\mathrm{c}}$ \\
Twig & $3.06 \pm 0.05^{\mathrm{a}}$ & $3.54 \pm 0.27^{\mathrm{a}}$ & $0.91 \pm 0.04^{\mathrm{b}}$ & $0.78 \pm 0.05^{\mathrm{b}}$ \\
Foliage & $6.06 \pm 0.11^{\mathrm{a}}$ & $5.79 \pm 0.38^{\mathrm{a}}$ & $0.39 \pm 0.02^{\mathrm{b}}$ & $0.55 \pm 0.03^{\mathrm{b}}$ \\
Above-ground total & $50.62 \pm 0.52^{\mathrm{a}}$ & $25.72 \pm 0.11^{\mathrm{b}}$ & $9.87 \pm 0.33^{\mathrm{c}}$ & $8.85 \pm 0.54^{\mathrm{c}}$ \\
Root & $10.13 \pm 0.16^{\mathrm{a}}$ & $3.63 \pm 0.26^{\mathrm{b}}$ & $2.87 \pm 0.12^{\mathrm{bc}}$ & $2.66 \pm 0.16^{\mathrm{c}}$ \\
Total & $60.75 \pm 0.67^{\mathrm{a}}$ & $29.35 \pm 2.32^{\mathrm{b}}$ & $12.74 \pm 0.45^{\mathrm{c}}$ & $11.51 \pm 0.71^{\mathrm{c}}$ \\
\hline
\end{tabular}

Note: EP, Eldar pine ; AC, Arizona cypress; M, mulberry; BL, black locust. Values in the same row followed by the same letter are not significantly different at $P<0.05$ level.

The comparison of carbon concentrations among the tree tissues showed significant differences among the different species (Table 4). For all four species, the carbon fraction of root, foliage and twig were similar while the carbon concentrations of stem, wood and bark as well as branch were different. The evaluation of the carbon sequestration potential requires careful consideration of the amount of carbon in the tree tissues, which, in most studies, was considered as $50 \%$ of the weight of the tree biomass (Thomas and Martin, 2012). The present study showed that the carbon concentration is different in the tissues for the different species. Coniferous had a higher tissue carbon value than deciduous (Table 4). Minami and Saka (2003) related these results to a lower level of lignification in coniferous. Another reason may be the differences in the lignin chemistry between the species (Campbell and Sederoff, 1996).

Table 4 Carbon concentrations in different part of the trees for the four plantations

\begin{tabular}{lcccc}
\hline \multirow{2}{*}{ Tree parts } & \multicolumn{4}{c}{ Tissue carbon concentration $(\%)$} \\
\cline { 2 - 5 } & EP & AC & M & BL \\
\hline Stem wood & $59.2 \pm 1.6^{\mathrm{a}}$ & $58.8 \pm 1.6^{\mathrm{a}}$ & $54.3 \pm 1.5^{\mathrm{a}}$ & $41.8 \pm 1.1^{\mathrm{b}}$ \\
Stem bark & $52.6 \pm 0.8^{\mathrm{ab}}$ & $47.8 \pm 1.1^{\mathrm{bc}}$ & $45.4 \pm 1.6^{\mathrm{c}}$ & $54.1 \pm 1.1^{\mathrm{a}}$ \\
Branch & $59.2 \pm 1.2^{\mathrm{a}}$ & $55.5 \pm 1.6^{\mathrm{ab}}$ & $54.5 \pm 2.1^{\mathrm{ab}}$ & $48.3 \pm 0.9^{\mathrm{b}}$ \\
Twig & $47.1 \pm 1.8^{\mathrm{a}}$ & $48.3 \pm 0.9^{\mathrm{a}}$ & $49.3 \pm 3.1^{\mathrm{a}}$ & $46.6 \pm 1.0^{\mathrm{a}}$ \\
Foliage & $47.0 \pm 0.4^{\mathrm{a}}$ & $47.6 \pm 0.4^{\mathrm{a}}$ & $42.2 \pm 1.9^{\mathrm{a}}$ & $45.1 \pm 1.4^{\mathrm{a}}$ \\
Root & $58.3 \pm 1.2^{\mathrm{a}}$ & $51.2 \pm 3.0^{\mathrm{a}}$ & $52.3 \pm 1.8^{\mathrm{a}}$ & $50.6 \pm 0.2^{\mathrm{a}}$ \\
\hline
\end{tabular}

Note: Mean \pm SD. Values in the same row followed by the same letter are not significantly different at $P<0.05$ level. 
The results of ANOVA indicated a significant difference between the above- and below-ground carbon storage for the four plantations. In all components of a tree, EP sequestrated more carbon in comparison to the other species. The amount of carbon sequestrated in the foliages and twigs were similar for EP and AC (Table 5).

\subsection{Soil carbon storage}

The carbon concentrations of various soil samples across the plantations provided a general picture of the carbon storage at different soil depths. Organic carbon concentrations of the four plantations were significantly different at $0-15$ and $15-30 \mathrm{~cm}$ depths (Fig. 1) but the carbon concentrations at the depth of $30-45 \mathrm{~cm}$ were similar for all the plantations. Considering the total soil carbon in all depths under the four plantations, the highest soil carbon storage was found in BL $\left(2.45 \mathrm{Mg} / \mathrm{hm}^{2}\right)$ and the lowest in EP plantation $\left(1.17 \mathrm{Mg} / \mathrm{hm}^{2}\right)$. EP and AC were similar in their soil carbon storage capacities. For all the plantations, soil carbon storage was higher than that under the control treatment.The potential soil carbon storage of the coniferous was less than that of the deciduous. The results indicated that the plantations can increase soil carbon storage up to five times more compared to the controlled.

Table 5 Carbon stored in different part of the trees for the four plantations

\begin{tabular}{ccccc}
\hline \multirow{2}{*}{ Tree parts } & \multicolumn{4}{c}{ Carbon $\left(\mathrm{Mg} / \mathrm{hm}^{2}\right)$} \\
\cline { 2 - 5 } & EP & AC & $\mathrm{M}$ & BL \\
\hline Stem wood & $14.17 \pm 0.59^{\mathrm{a}}$ & $6.17 \pm 0.42^{\mathrm{b}}$ & $1.86 \pm 0.07^{\mathrm{c}}$ & $1.13 \pm 0.04^{\mathrm{c}}$ \\
Stem bark & $2.03 \pm 0.06^{\mathrm{a}}$ & $0.76 \pm 0.05^{\mathrm{c}}$ & $0.53 \pm 0.01^{\mathrm{d}}$ & $1.26 \pm 0.06^{\mathrm{b}}$ \\
Branch & $8.14 \pm 0.30^{\mathrm{a}}$ & $2.38 \pm 0.27^{\mathrm{b}}$ & $1.94 \pm 0.12^{\mathrm{bc}}$ & $1.34 \pm 0.08^{\mathrm{c}}$ \\
Twig & $1.44 \pm 0.06^{\mathrm{a}}$ & $1.71 \pm 0.16^{\mathrm{a}}$ & $0.45 \pm 0.01^{\mathrm{b}}$ & $0.36 \pm 0.02^{\mathrm{b}}$ \\
Foliage & $2.85 \pm 0.07^{\mathrm{a}}$ & $2.76 \pm 0.19^{\mathrm{a}}$ & $0.16 \pm 0.02^{\mathrm{b}}$ & $0.25 \pm 0.02^{\mathrm{b}}$ \\
Above-ground total & $28.62 \pm 0.69^{\mathrm{a}}$ & $13.78 \pm 1.06^{\mathrm{b}}$ & $4.94 \pm 0.20^{\mathrm{c}}$ & $4.35 \pm 0.20^{\mathrm{c}}$ \\
Root & $5.9 \pm 0.21^{\mathrm{a}}$ & $1.85 \pm 0.12^{\mathrm{b}}$ & $1.50 \pm 0.01^{\mathrm{b}}$ & $1.34 \pm 0.08^{\mathrm{b}}$ \\
Total & $34.53 \pm 0.88^{\mathrm{a}}$ & $16.63 \pm 1.14^{\mathrm{b}}$ & $6.44 \pm 0.21^{\mathrm{c}}$ & $5.69 \pm 0.29^{\mathrm{c}}$ \\
\hline
\end{tabular}

Note: Mean \pm SD. Values in the same row followed by the same letter are not significantly different at $P<0.05$ level.

\subsection{Carbon storage in different part of the trees of the plantations}

Figure 2 shows the amount of the ecosystem carbon storage in the trees of the four plantations. In this study, the ecosystem carbon storage included soil, forest floor, and the above- and below-ground tree components. The maximum carbon storage value was found in the EP plantation $\left(37.8 \mathrm{Mg} / \mathrm{hm}^{2}\right)$,

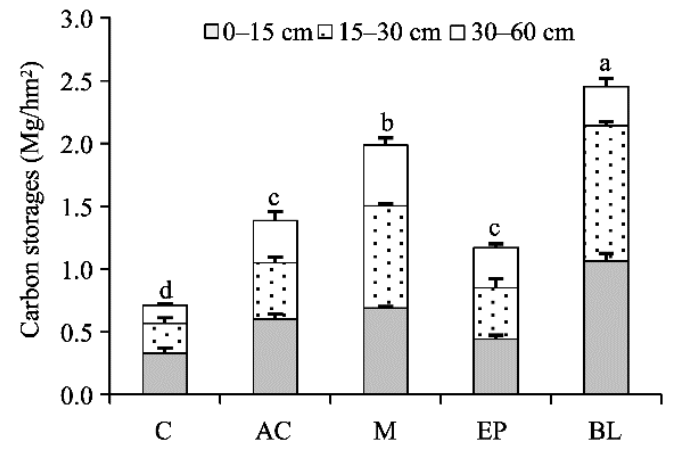

Fig. 1 Soil carbon storage values of the four tree plantations and the control area. AC, Arizona cypress; M, mulberry; EP, Eldar pine ; BL, black locust; C, control area. The same letters at the bottom of the bars indicate no significant difference at $P<0.05$ level.

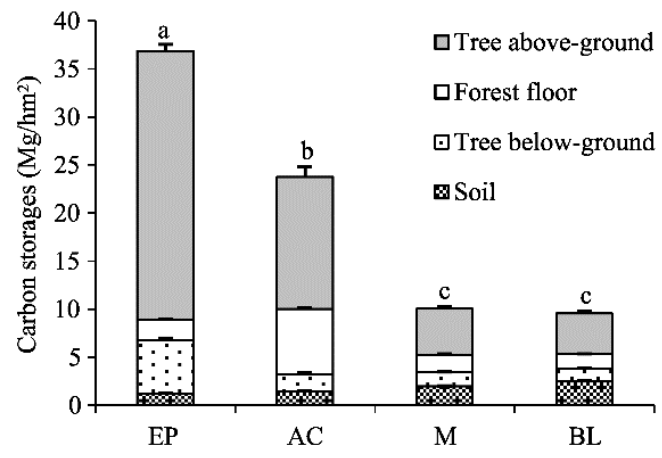

Fig. 2 Carbon storage in different tree parts of the four plantations. Vertical lines denote standard deviations. The same letters at the top of the bars indicate no significant difference at $P<0.05$ level. 
the values were getting lower as the following order: $23.8 \mathrm{Mg} / \mathrm{hm}^{2}$ for $\mathrm{AC}, 10.2 \mathrm{Mg} / \mathrm{hm}^{2}$ for M and $9.7 \mathrm{Mg} / \mathrm{hm}^{2}$ for BL. The highest carbon storage was found in the above-ground components, ranged from $45.1 \%$ to $75.8 \%$ (EP, 75.8\%; $\mathrm{AC}, 58.0 \%$; M, 48.4\%; BL, 45.1\%). In the below-ground component, the carbon storage ranged from $7.8 \%$ to $15.6 \%$ (EP, $15.6 \%$; $\mathrm{AC}, 7.8 \%$; $\mathrm{M}, 14.5 \%$; $\mathrm{BL}$, $13.9 \%$ ). The forest floor contained 5.5\%-28.4\% (EP, 5.5\%; AC, 28.4\%; M, 17.6\%; BL, 15.6\%) of the ecosystem carbon storage and the percentage of soil carbon in the four plantations was limited to $3.1 \%-25.6 \%$ (EP, 3.1\%; AC, 5.8\%; M, 19.5\%; BL, 25.4\%). Forest floor materials may act as the source and sink in the global carbon dioxide cycle (Klopatek, 2002). In this study, forest floor includedthe litter production of living vegetations. Comparing to the other plantations, AC plantation has the highest level of carbon in the forest floor. This was inconsistent with the study by Zheng et al. (2008), which reported a higher forest floor carbon for coniferous species. This issue could be related to the practical management in collecting litter of the EP plantation for preventing fires.

The main part of the carbon sink in the soil carbon sequestration is organic matter (Lal, 1999). One aim of this study was to compare soil carbon storage among BL, EP, M and AC stands. The results showed that the amount of soil carbon storage for deciduous species is higher than for the coniferous and BL had the highest soil carbon sequestration rate. The additional fine roots in the soil is an important reason for soil carbon gain (Waring and Running, 1998; Clark et al., 2001; Yang et al., 2004), as deciduous trees have highly ramified fine roots (Bauhus and Messier, 1998) while, in contrast, coniferous have a strategy to slow the development of the fine root system. Another reason for these results may be the slower decomposition of coniferous litter (Law et al., 2001). The differences in the quality of the litter inputs and litter carbon decay under the different plantations may cause the differences in the amount of carbon in the soil. It should be considered that the quality of the litter inputs and litter carbon can affect not only the carbon stored in the forest floor but also nitrogen pools, earthworm abundance, fungal growth, soil acidity and mineral nutrient content in soil which are directly linked to the carbon fluxes in plantations and consequently the amount of carbon stored in the forest floor (Hansson, 2011).

\subsection{Carbon allocation and root mass fraction}

Figure 3 displays a general picture of biomass allocation in different tree components, which shows that the above-ground carbon storage was the largest section in the carbon pools of the plantations. The deciduous with larger crowns and root systems allocate more carbon to these parts in comparison to the coniferous.

The root mass fraction (RMF) is one of the variables that describes plant biomass allocation (Porter et al., 2012). RMF was calculated as root biomass/total biomass. Figure 4 shows root mass fraction for different plantations and the rate for deciduous trees was higher than the coniferous. One of the important components in plant life histories is the allocation of carbon to growth (Mooney,

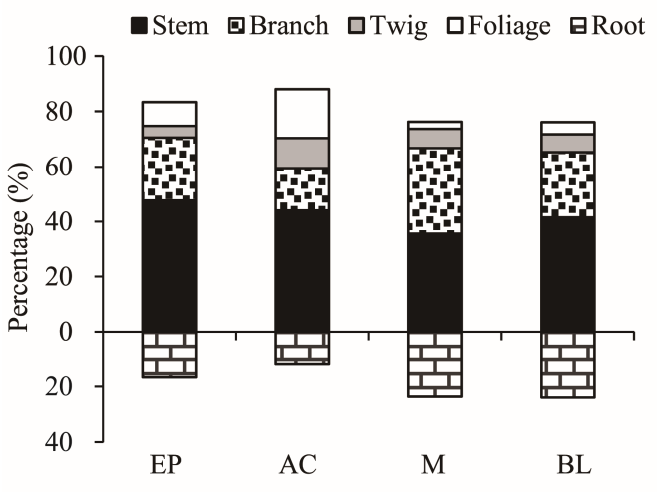

Fig. 3 Carbon allocation at different compartments of the planted trees

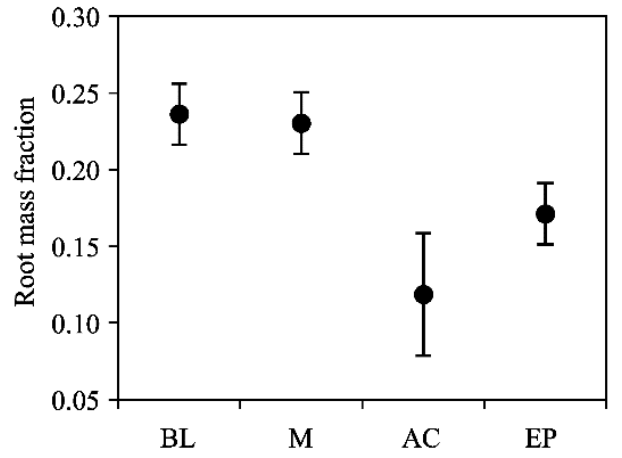

Fig. 4 Root mass fraction in different tree species. Vertical lines denote standard deviations 
1972; Bloom et al., 1985). The amount of biomass allocation at different components of the four plantations is shown in Table 3. According to these results, the biomass allocation at both above- and below-ground was different between the deciduous and the coniferous. Poorter and Nagel (2000) and Reich (2002) reported that biomass allocation in plants is hardly affected by environmental factors.

\section{Conclusion}

Plantations can play a significant role in reducing atmospheric carbon dioxide. In this study, we compared the carbon storage among the four plantations at different soil depths, at the forest floor, as well as between the above- and below-ground tree components. The results of the study showed that the carbon storage potential for coniferous plantations was higher than that for the deciduous and Eldar pine had the highest carbon storage rate. In plantation management plans the potential for carbon dioxide fixation of trees should be considered. For the purpose of sequestrating atmospheric carbon dioxide by planting trees in areas with low rainfall, especially when waste water for irrigation is available, we recommend to plant Eldar pines.

It is important to consider different carbon storage patterns among the plantations. Some species store more carbon in soil while the others store more carbon in their living tissues. Each species, due to characteristics of physiology, phenology and morphology, may need to be managed in different ways. Species selection can affect many aspects of ecosystem functions and services to fulfill multiple goals and purposes. Therefore carbon storage potential should not be the only criterion for the selection.

\section{Acknowledgements}

The authors gratefully acknowledge the support from the Mobarakeh Steel Company. We also wish to thank Mr. Eng. Mohamad Reza BABAEI and Mr. Eng. Mojtaba GHORBANI for their assistance in field works, and Mrs. Ellen VUOSALO TAVAKOLI (University of Mazandaran) for her help in checking grammar and spelling.

\section{References}

Abdinezhad R. 2012. General laws for urban lands and properties. Organizations and methods improvement department. (in Iranian)

Aguirre-Salado C A, Treviño-Garza E J, Aguirre-Calderón O A, et al. 2014. Mapping aboveground biomass by integrating geospatial and forest inventory data through a $k$-nearest neighbor strategy in North Central Mexico. Journal of Arid Land, 6(1): 80-96.

TSI Incorporated. 2004. Combustion analysis basics: an overview of measurements, methods and calculations used in combustion analysis. The USA: TSI Incorporated, 35. http://www.tsi.com/uploadedFiles/_Site_Root/Products/Literature/Handbooks/ CA-basic-2980175.pdf.

Bauhus J, Messier C. 1999. Soil exploitation strategies of fine roots in different tree species of the southern boreal forest of eastern Canada. Canadian Journal of Forest Research, 29(2): 260-273.

Bipal J, Mrinmo M. 2010. Impact of Climate Change on Natural Resource Management. Netherlands: Springer.

Bloom A J, Chapin F S, Mooney H A. 1985. Resource limitation in plants-an economic analogy. Annual Review of Ecology and Systematics, 16(4): 363-392.

Campbell M M, Sederoff R R. 1996. Variation in lignin content and composition (mechanisms of control and implications for the genetic improvement of plants). Plant Physiology, 110(1): 3-13.

Clark D A, Brown S, Kicklighter D W, et al. 2001. Measuring net primary production in forests: concepts and field methods. Ecological Applications, 11(2): 356-370.

Coyle D R, Coleman M D, Aubrey D P. 2008. Above- and below-ground biomass accumulation, production, and distribution of sweetgum and loblolly pine grown with irrigation and fertilization. Canadian Journal of Forest Research, 38(6): $1335-1348$.

Hansson K. 2011. Impact of tree species on carbon in forest soils. PhD Dissertation. Uppsala: Swedish University of Agricultural Sciences.

Kaul M, Mohren G M J, Dadhwal V K. 2010. Carbon storage and sequestration potential of selected tree species in India. Mitigation and Adaptation Strategies for Global Change, 15(5): 489-510.

Klopatek J M. 2002. Belowground carbon pools and processes in different age stands of Douglas-fir. Tree Physiology, 22(2-3): 97204. 
Lal R. 1999. Soil management and restoration for C sequestration to mitigate the accelerated greenhouse effect. Progress in Environmental Science, 1(4): 307-326.

Law B E, Thornton P E, Irvine J, et al. 2001. Carbon storage and fluxes in ponderosa pine forests at different developmental stages. Global Change Biology, 7(7): 755-777.

Lemus R, Lal R. 2005. Bioenergy crops and carbon sequestration. Critical Reviews in Plant Sciences, 24(1): 1-21.

Li Y Q, Zhao X Y, Zhang F X, et al. 2014. Accumulation of soil organic carbon during natural restoration of desertified grassland in China's Horqin Sandy Land. Journal of Arid Land, 7(3): 382-340.

McPherson E G, Simpson J R. 1999. Carbon dioxide reduction through urban forestry: Guidelines for professional and volunteer tree planters. In: USDA Forest Service, PSW General Technical Report. No. PSW-GTR-171. Albany, CA, USA.

Minami E, Saka S. 2003. Comparison of the decomposition behaviors of hardwood and softwood in supercritical methanol. Journal of Wood Science, 49(1): 73-78.

Mooney H A. 1972. The carbon balance of plants. Annual Review of Ecologyand Systematics, 3(1): 315-346.

Poorter H, Nagel O. 2000. The role of biomass allocation in the growth response of plants to different levels of light, $\mathrm{CO}_{2}$, nutrients and water: a quantitative review. Australian Journal of Plant Physiology, 27(6): 595-607.

Poorter H, Niklas K J, Reich P B, et al. 2012. Biomass allocation to leaves, stems and roots: Meta-analyses of interspecific variation and environmental control. New Phytologist, 193(1): 30-50.

Prihar S S, Hundal S S. 1971. Determination of bulk density of soil clod by saturation. Geoderma, 5(4): 283-286.

Reich P B. 2002. Root-shoot relations: optimality in acclimation and adaptation or the 'Emperor's New Clothes'? In: Waisel Y, Amram E, Kafkafi U. Plant Roots: The Hidden Half (3 ${ }^{\text {rd }}$ ed.). New York: Marcel Dekker Inc., 205-220.

Schulze E D, Beck E, Müller-Hohenstein K. 2005. Plant Ecology. Berlin: Springer.

Schumacher B A. 2002. Methods for the determination of total organic carbon (TOC) in soils and sediments. In: Ecological Risk Assessment Support Center. NCEA-C-1282, EMASC-001. Las Vegas: U.S. Environmental Protection Agency.

Thomas S C, Martin A R. 2012. Carbon content of tree tissues: a synthesis. Forests, 3(2): 332-352.

Verwijst T, Telenius B. 1999. Biomass estimation procedures in short rotation forestry. Forest Ecology and Management, 121(1-2): 137-146.

Waring R H, Running S W. 1998. Forest Ecosystems: Analysis at Multiple Scales. UK: Elsevier Academic Press.

Woodbury P B, Smith J E, Heath L S. 2007. Carbon sequestration in the U. S. forest sector from 1990 to 2010. Forest Ecology and Management, 241(1-3): 14-27.

Yan F, Wu B, Wang Y J. 2013. Estimating aboveground biomass in Mu Us Sandy Land using Landsat spectral derived vegetation indices over the past 30 years. Journal of Arid Land, 5(4): 521-530.

Yang Y S, Chen G S, Guo J F, et al. 2004. Decomposition dynamic of fine roots in a mixed forest of Cunninghamia lanceolata and Tsoongiodendron odorum in mid-subtropics. Annals of Forest Science, 61(4): 65-72.

Zheng H, Ouyang Z Y, Xu W H, et al. 2008. Variation of carbon storage by different reforestation types in the hilly red soil region of southern China. Forest Ecology and Management, 255(3-4): 1113-1121. 